\title{
How Environment Dynamics Affects Production Scheduling: Requirements for Development of CPPS Models
}

Cátia Alves

Assistant Professor Centro ALGORITMI, Universidade do Minho Department of Production and Systems Engineering, University of Minho Portugal

\section{Goran D. Putnik}

Professor

Centro ALGORITMI, Universidade do Minho Department of Production and Systems Engineering, University of Minho Portugal

\section{Leonilde Varela}

Assistant Professor Centro ALGORITMI, Universidade do Minho Department of Production and Systems Engineering, University of Minho Portugal
Production scheduling can be affected by many disturbances in the manufacturing system, and consequently, the feasible schedules previously defined became obsolete. Emerging of new technologies associated with Industry 4.0, such as Cyber-Physical Production Systems, as a paradigm of implementation of control and support in decision making, should embed the capacity to simulate different environment scenarios based on the data collected by the manufacturing systems. This paper presents the evaluation of environment dynamics effect on production scheduling, considering three scheduling models and three environment scenarios, through a case study. Results show that environment dynamics affect production schedules, and a very strong or strong positive correlation between environment dynamics scenarios and total completion time with delay, over three scheduling paradigms. Based on these results, the requirement for mandatory inclusion of a module for different environment dynamics scenarios generation and the corresponded simulations, of a Cyber-Physical Production Systems architecture, is confirmed.

Keywords: Environment dynamics scenarios, Production Scheduling, Cyber-Physical Production Systems, Real Time Mangament, Dynamic Scheduling.

\section{INTRODUCTION}

The fourth Industrial Revolution, named Industry 4.0, and the associated development of advanced information and communication technologies (ICT), challenged the traditional approaches in manufacturing.

Numerous algorithms were developed to predict, for example, maintenance actions or production scheduling, considering the production dynamics. Cyber-Physical Production Systems (CPPS) were developed as a paradigm of implementation of control and support in decision making. Through historical data, the CPPS enables predictions for what might happen in the future. However, uncertainty in some environments could be so volatile, that it can influence the forecasts based on historical data.

It means that different forecasts could be made on the same historical data. In other words, different "futures" could be imagined, based on the same historical data. These different "futures", or different forecasts, could be called "scenarios" (a scenario represents " $a$ synopsis of a possible course of action or events" [1] or "a postulated sequence of possible events" [2]).

The main motivation for this paper is to answer the question: if several scenarios of environmental dynamics are investigated, what might happen to the performance of the operation schedules in a manufacturing system? How different scenarios of the environment

Received: January 2021, Accepted: September 2021

Correspondence to: Dr Cátia Alves. ALGORITMI

Research Center, University of Minho

Campus of Azurém, 4800-058 Guimarães. Portugal

E-mail: catia.alves@dps.uminho.pt

doi:10.5937/fme2104827A

(C) Faculty of Mechanical Engineering, Belgrade. All rights reserved dynamics will affect the operation schedules?. (Note: This is different from contribution to the prediction modelling based on historical data, and/or considering different models to generate forecasts, which is the scientific issue per se.)

This paper contributes to the answer to the proposed questions with the following aims:

(1) to evaluate how the environment dynamics affect production schedules, and

(2) to contribute to the future CPPS models developments, in the context of requirements for consi-deration of the environment dynamics, e.g. by considering different scenarios.

The paper is further organized as follows.

Section 2 presents the related work on environment dynamics in production scheduling, and CPPS. In Section 3 a framework for environment dynamics scenarios use in CPPS is presented. Section 4 presents a case study for the evaluation of how environment dynamics affects production scheduling. Further, in Section 5 some requirements for the development of CPPS models are presented. Section 6 presents the main conclusions of this paper.

\section{RELATED WORK}

Environment dynamics generates disturbances that can control and affect the production scheduling. Disturbances are unplanned events that could affect the production scheduling, such as machine configurations, new-products inclusion, market demand, equipment failures [3], among others.

Some authors had addressed disturbances in production scheduling research, through reconfiguration or re- 
scheduling. The term of rescheduling could be used in reactive scheduling and/or dynamic scheduling [4,5]. In this paper, the terms reconfiguration or rescheduling will be used for dynamic scheduling.

Dynamic scheduling is considered when the list of jobs arrival is partially or totally unknown, at the initial scheduling planning [6], representing disturbances in the scheduling plan, implying corresponding adaptations or reconfiguration of the schedules. To adapt to production changes, Antonelli and Bruno [7] presented a procedure for tasks (of a job) dynamic assignment, in which real time control for the task dynamic reassignment is included.

The real time control for dealing with the disturbances leads to the generation of Big Data, as a result of continuous real time data collection of all changes in the manufacturing process, captured by sensors, usually stored in large databases.

In the scenario of Industry 4.0, these data are supposed to be processed by a CPPS. In the last years, the research on CPPS starts to grow up in the manufacturing area. Publications under the term "Cyber-physical Production Systems" on the Web of Science ${ }^{\mathrm{TM}}$, shows the growth of this research, especially in the areas of manufacturing and scheduling, e.g see [8] for a review of scheduling in CPPS.

One of the main features of CPPS is the capability of processing Big Data [9] to deal in (near) real time with the functional requirements, including control under the conditions of environment dynamics, which implies the reconfiguration of the scheduling decisions.

Considering dynamic scheduling in CPPS, Nikolakis et al. [10] discussed an end-to-end framework for a small scale CPPS considering the dynamic planning and scheduling, to adapt the production schedule to the disturbances of the manufacturing system, such as resources availability and failures. Another disturbance that is considered in scheduling research is the parameter of new job arrivals, addressed in real time production scheduling by [11].

Zhu and Zhang [12] proposed a CPPS framework of a smart monitoring system considering dynamics in the physical part of the CPPS, but the environment dynamics is not considered for the process of simulation, and decision making, within the cyber part of the CPPS.

Meissner and Aurich [13] analysed the impact of CPPS in production planning and scheduling, and they consider dynamics as the capacity of alternative process plan to adapt the scheduling, due to for example a machine breakdown.

Jiang et al. [14] states that it is difficult to apply the traditional scheduling policies to the CPPS due to the characteristics of CPPS, such as intelligence and distribution.

To deal with the characteristics of CPPS, Machine Learning has been explored to create new solutions for scheduling under CPPS, based on predictions or forecasts from previous schedules. The scheduling predictions/forecasts generated by the combination of big data and machine learning techniques drive smart planning decisions in manufacturing [15]. Also, Machine Learning in CPPS can be used to "reconfigure the manufacturing system without great effort or physically changing the system configuration" [16].

Recently, studies related to prediction in scheduling have emerged. For example, Morariu and Borangiu [17] proposed a time series forecasting model for dynamics scheduling using a robotic resource that learned and detected patterns to predict the next pattern.

The use of prediction in scheduling is based on timeseries forecasting, considering the pattern of historical data from which forecasted data will be generated. For example, if the historic data pattern shows some trend in data it is possible to predict that in the future horizon (scheduling horizon) the data will follow the trend pattern. The prediction is often used in nature phenomena, such as wind power density studies [18].

However, in the literature referred above, dynamic scheduling based on different scenarios are not considered. In the literature referred, forecasts are usually generated from time series, based on the history, i.e., following the historical pattern. In turbulent and uncertain environments, in addition to forecasts generated based on history, other scenarios that may not follow the historical pattern should be considered.

In this sense, consideration of different "future" scenarios and their impact on operations schedules in a manufacturing system, makes the paper's original contribution.

\section{A FRAMEWORK FOR ENVIRONMENT DYNA- MICS SCENARIOS USE IN CPPS}

Environment modelling is a common issue of any simulation.

Concerning non-linear dynamics, it was used for modelling manufacturing systems behaviour and simulations, e.g. [19-21]. Concerning in particular the CPPS, dynamic environment modelling is addressed in [22]. Dynamic environment is modelled as a set of beliefs about the state of its environment from sensor information using a trust model, whose role is to deal with the uncertainty in the input data that consists of sensor information and predictions about the state of the environment from other agents, participants in the CPPS.

The environment model in fact represents a context in which a system could be situated [23].

In manufacturing, CPPS embeds simulation to support learning and subsequent decision making [24]. [24] proposed an original generic architecture for a CPPS from which other CPPS models can be derived, such as:

- Traditional Production System (PS) or Manufacturing System (MS);

- "Classical" CPPS (CPPS ${ }^{0}$ ) (without learning);

- $\quad$ CPPS with single loop learning $\left(\mathrm{CPPS}^{1}\right)$;

- $\quad$ CPPS with double loop learning $\left(\mathrm{CPPS}^{2}\right)$.

In this paper, the "Classical" CPPS, that is CPPS ${ }^{0}$ is considered (Figure 1). The "Classical" CPPS does not consider Machine Learning, as the Machine Learning functionality is not considered in this paper.

Considering the environment dynamics as a principal topic in this paper, the special attention is given to the CPPS module "Environment Model Generator", presented in Figure 1 (detail B). 


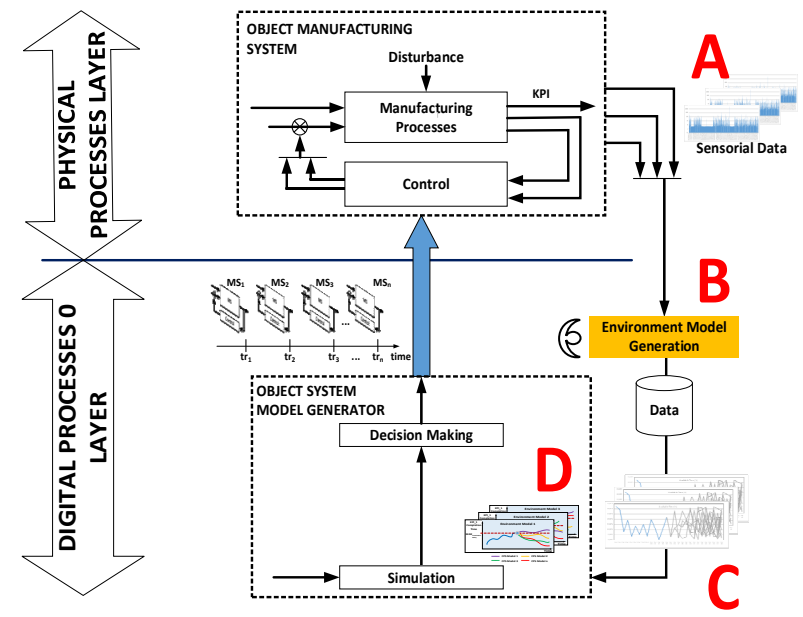

Figure 1. CPPS $^{0}$ logical architecture adapted from [24]

The "Environment Model Generator" could be named Dynamic Environment Model Generator Module (DEMGM). The DEMGM, within the CPPS, is a mechanism (algorithm) for mapping input time series (data streams from the manufacturing system sensors /status - real system parameters) to the output forecasts time series (forecasted, or projected) for the system parameter $k$, i.e.:

$$
D E M G M:\left\{S D_{k}\right\} \rightarrow\left\{T_{0}, T_{1}, \ldots, T_{i}, \ldots, T_{H}\right\}
$$

where,

$S D$ are sensorial data for parameter $k$ (detail A at Figure 1) (from one sensor),

$H$ is the horizon of forecasting, i.e. $H$ time units ahead from the time moment which is initial moment for forecasting, and

$T_{i}$ is the time series for the time interval $[i ; H]$, where $i$ means that the interval $[i ; H]$ starts at the time moment $i$, which is $i$ time units ahead from the initial moment of the forecasting. (detail $\mathrm{C}$ at Figure 1).

The DEMGM differs from traditional approaches. Traditionally, the data collected from the manufacturing process is used to predict the data for future decision making, for one scenario.

The environment dynamics in CPPS, considering DEMGM for one scenario, is modelled as follows.

At time unit $i$ is generated a forecast for a performance measure (parameter) defined, e.g. 'processing time', till the horizon of forecasting, $H$ time units. At the time unit $i+1$, due to the dynamic nature of the environment, the previous forecast may be totally invalid, and a new forecast is to be made till the horizon of forecasting $H$.

In equation (1), the term $\left\{T_{0}, T_{1}, \ldots, T_{i}, \ldots, T_{H}\right\}$ means a set of time series in which time serie $T_{0}$ is the time series starting in $\mathrm{t}_{0}, T_{1}$ is the time series starting in $t_{1}, T_{2}$ is the time series starting in $t_{2}$, etc. up to the $t_{H}$, where the value of $H$ is chosen by the planner.

The difference between the traditional approach and the environment dynamics presented in this paper is that at the moment $i+1$ the previous forecast becomes invalid and it should not be considered anymore. The process will be the same for the next $i$ time units ahead from the initial moment of the forecasting.
This process will continue to repeat, meaning that at each reconfiguration moment a new forecast will start until the end of the forecasting horizon, or in other words, till the end of the planning horizon.

DEMGM for one scenario consists of 4 sub-modules (Figure 2) with the functionalities:

1) time series data transformation,

2) time series parameters extraction,

3) forecast time series parameters decision/design,

4) forecast (forecasted/projected data) time series generator in accordance with the parameters decided/designed (projected).

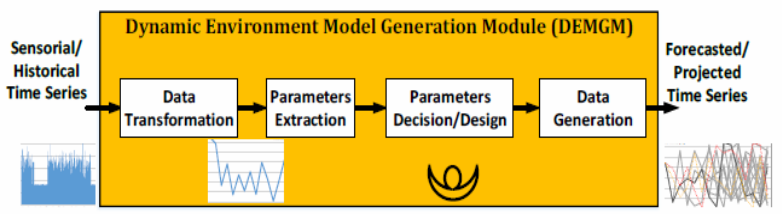

Figure 2. Logical Architecture of Dynamic Environment Model Generator Module (DEMGM).

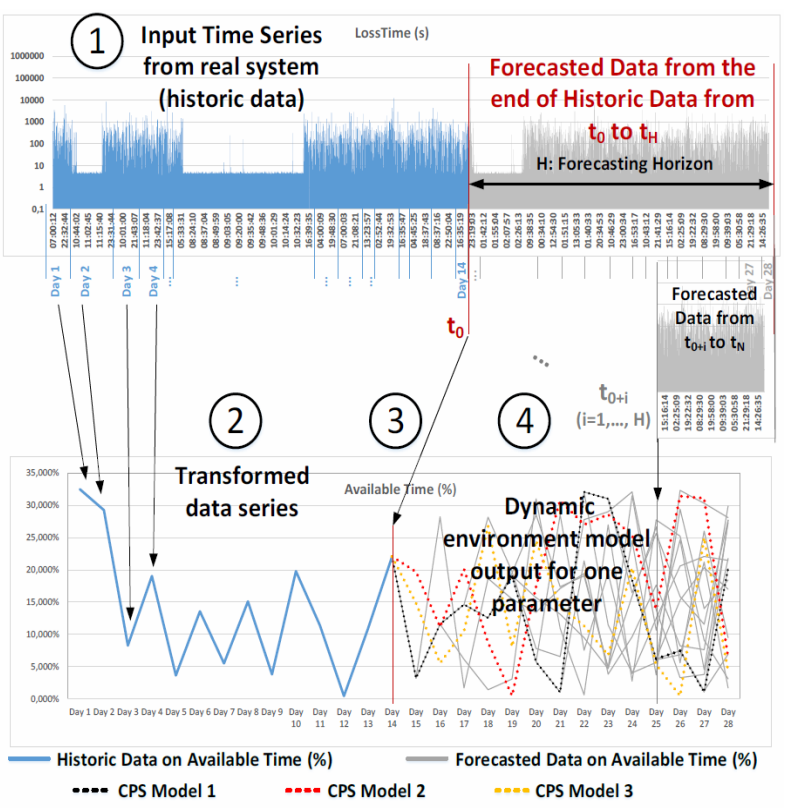

Figure 3. DEMGM input time series, transformed data series and dynamic environment model output for one parameter.

Figure 3 shows graphically INPUT time series (data streams from the real system sensors), transformed time series data in a format more adequate for the further process, and generated OUTPUT forecasts time series (forecasted, or projected), i.e. the generated dynamic environment model (for one parameter only).

Figures 2 and 3 refer only to one scenario, based on historical data, which is the traditional approach. As can be seen in Figure 1 (detail C), different scenarios must be generated through DEMGM that will serve as input for the simulation (detail D at Figure 1).

Thus, equation (1) only refers to one scenario, considering only one time series for the time interval.

As observed in Figure 1 (detail C), the DEMGM should generate time series for different scenarios. Thus, based on the input of sensorial data for a parameter $k$, DEMGM outputs forecasts time series generated for all scenarios $[1, \mathrm{~S}]$ : 


$$
\begin{aligned}
D E M G M:\left\{S D_{k}\right\} \rightarrow & \left\{T_{0}^{1}, T_{1}^{1}, \ldots, T_{i}^{1}, \ldots, T_{H}{ }^{1},\right. \\
& T_{0}^{2}, T_{1}^{2}, \ldots, T_{i}{ }^{2}, \ldots, T_{H}{ }^{2}, \\
& \ldots, \\
& T_{0}{ }^{s}, T_{0}{ }^{s}, \ldots, T_{i}^{s}, \ldots, T_{H}{ }^{s}, \\
& \ldots \\
& \left.T_{0}{ }^{S}, T_{1}{ }^{S}, \ldots, T_{i}{ }^{S}, \ldots, T_{H}{ }^{s}\right\}
\end{aligned}
$$

where,

$T_{i}^{s}$ is the time series for the scenario $s$ (detail D at Figure 1). Number of scenarios is 1 to $S$.

The dynamic environment model can considerer the traditional time-series parameters, used in forecasting generation, such as variation of the amplitude, trends, seasonality, control limits (upper and lower), the probability distribution (uniform, normal, binomial, exponential).

The dynamic environment model also needs to consider variations of the nominal data to reflect the environment dynamics, as lower variations of data from the nominal data mean lower environment dynamics and higher variations of data mean higher environment dynamics. The nominal data is considered as the technological constraints presented in the process plan for one product.

\section{ENVIRONMENT DYNAMICS EFFECT IN PRO- DUCTION SCHEDULING}

\subsection{Experimentation plan}

In this study a group of 15 machines was considered, on which operation 1 (OP1) can be processed in only one machine from the set of machines (Machine 1, Machine 2 , Machine 3$\}$, and operation 2 (OP2) can be processed in only one machine from the set of machines \{Machine $4, \ldots$, Machine 15 \}

Only one parameter for the disturbance was considered: the availability of the machines.

In this study, two different products, implying two different process plans (one process plan for each type of product) were considered, with their respective nominal technological processing time in units of time (Table 1).

The number of jobs considered in this study were: 10 jobs, 20 jobs, 40 jobs, and 100 jobs.

Each job is composed of two operations. To each job it is associated the production of one piece or one product, following the description within one process plan, with the associated nominal values for the operation time duration (processing time) in each machine. One process plan can be applied to different jobs, but to each job corresponds only one process plan.

Three environment scenarios were considered with different variations of amplitude ( $0 \%, 50 \%$ and $100 \%)$. In reality, and considering environment dynamics, these nominal values will be never realized; the operations are executed with different processing time than forecasted/projected.

In this study, the processing time value along the time was generated randomly from the nominal process plan input data. Considering the processing time des- cribed in the process plan, the data generated for the environment dynamics data is given in the following example: if the processing time is 4 , the value generated belongs to the interval of $[4,8]$ for $100 \%$ of dynamics variation of amplitude, or $[4,6]$ for $50 \%$ of dynamics

\begin{tabular}{|c|c|c|c|}
\hline & \multicolumn{2}{|c|}{ Nominal Processing Time } \\
\hline & & Process Plan 1 & Process Plan 2 \\
\hline Machine 1 & \multirow{3}{*}{ OP1 } & 4 & 5 \\
\hline Machine 2 & & 5 & 6 \\
\hline Machine 3 & & 6 & 7 \\
\hline Machine 4 & \multirow{12}{*}{ OP2 } & 6 & 7 \\
\hline Machine 5 & & 5 & 7 \\
\hline Machine 6 & & 3 & 7 \\
\hline Machine 7 & & 1 & 3 \\
\hline Machine 8 & & 2 & 2 \\
\hline Machine 9 & & 5 & 4 \\
\hline Machine 10 & & 7 & 5 \\
\hline Machine 11 & & 4 & 2 \\
\hline Machine 12 & & 6 & 1 \\
\hline Machine 13 & & 7 & 1 \\
\hline Machine 14 & & 5 & 1 \\
\hline Machine 15 & & 7 & 2 \\
\hline
\end{tabular}
variation of amplitude. This is because the value of time cannot be less than the values presented in the process plan, because of technological constraints.

Table 1. Nominal processing time per process plan

The environment dynamics scenarios were simulated over 3 scheduling models:

- Scheduling Model 1: control and decision making under the fixed horizon with reconfigurations scheduling paradigm.

- Scheduling Model 2: control and decision making under the rolling horizon scheduling paradigm.

- Scheduling Model 3: control and decision making under the real time management scheduling paradigm.

The first scheduling model, the fixed horizon with reconfigurations scheduling paradigm, considers the scheduling of all jobs (10, 20, 40, 100, for each case) among the resources (machines), till the completion time of all jobs scheduled.

The second scheduling model, the rolling horizon scheduling paradigm, considers the scheduling of the jobs $(10,20,40,100$, for each case) among the resources (machines), till the rolling horizon (planning horizon). In this case, some jobs are not scheduled during the rolling horizon. The remaining jobs could be scheduled in the next rolling horizon.

The third scheduling model, the real time management scheduling paradigm, considers the scheduling of the jobs $(10,20,40,100$, for each case) among the resources (machines), that are able to be scheduled within the reconfiguration period.

Note that in all three scheduling models presented the reconfiguration period is 1 unit of time.

Additionally, it has been considered the cumulative delay, i.e. the delay "in the function of the executed planned schedule elapsed time" [25]. See more details on cumulative delay in [25].

In this study, schedule's optimization is not the demonstration objective, as one of the paper's 
objectives is to evaluate how environment dynamics could affect production schedules.

\subsection{Simulations and results}

Simulations ran at the computer Intel ${ }^{\circledR}$ Core $^{\mathrm{TM}}$ i7-7700 CPU@3.60GHz, 32.0 Gb (RAM), with a simulator developed by the authors.

The simulation results of the 3 scheduling models tested in 3 environment scenarios (environment variation of amplitude of the nominal values of $0 \%, 50 \%$, and $100 \%$ ) are graphically presented in Figure 4, Figure 5 , Figure 6 , respectively. The same results are presented in Table 2 for better readability.

Figure 7, Figure 8, Figure 9, and Figure 10 show the simulation results obtained for the total completion time with delay, in function of the environment dynamics, for 10, 20, 40 and 100 jobs scheduled, respectively.

Table 2. Simulation results of the 3 scheduling models tested in 3 environment scenarios, i.e. over 3 environment models

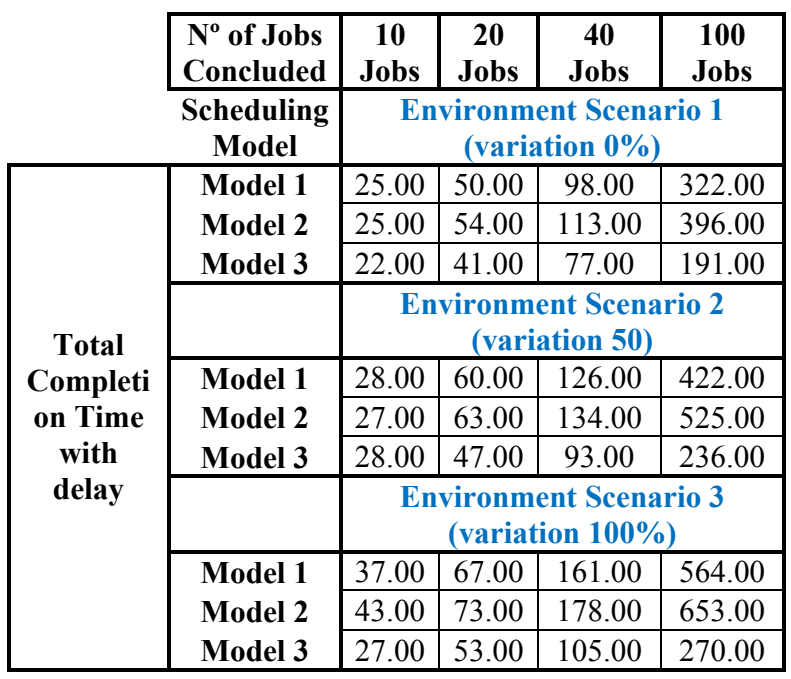

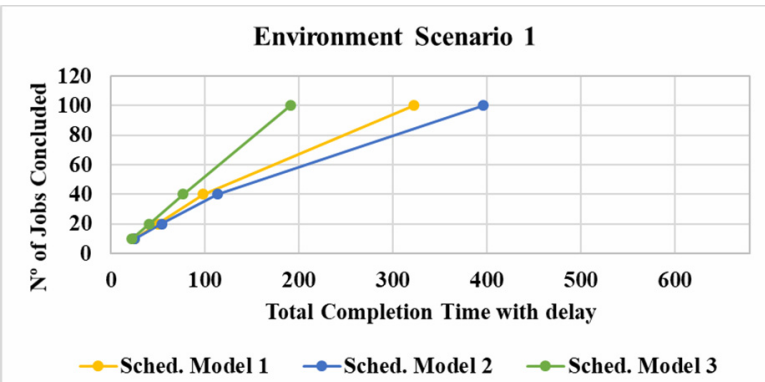

Figure 4. Simulation results of 3 Scheduling Models over the environment scenario 1 (variation of amplitude $0 \%$ )

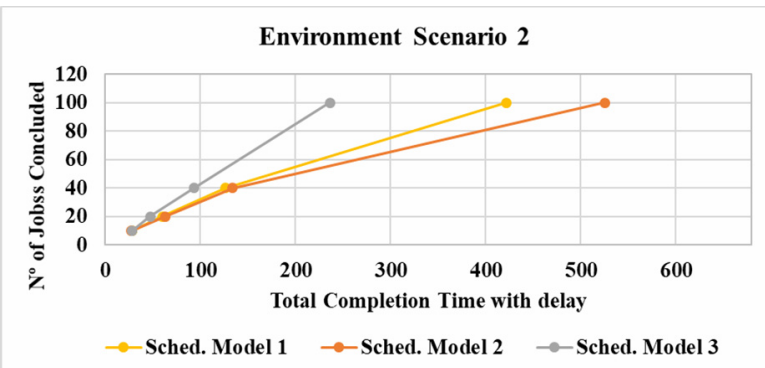

Figure 5. Simulation results of 3 Scheduling Models over the environment scenarios (variation of amplitude $50 \%$ )

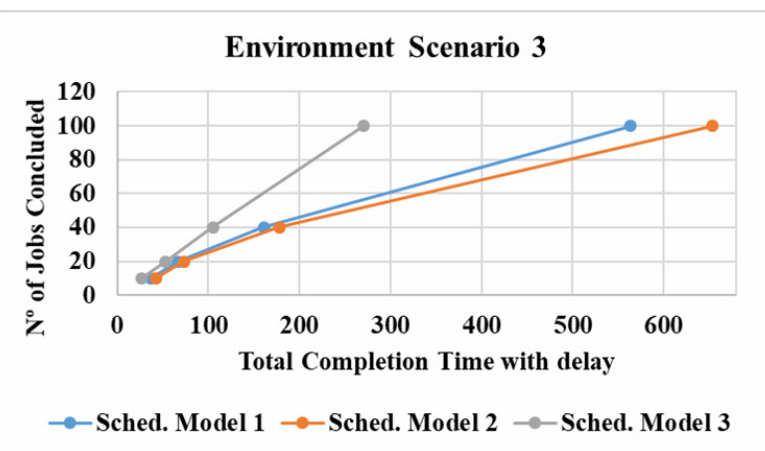

Figure 6. Simulation results of 3 Scheduling Models over the environment scenarios (variation of amplitude 100\%)

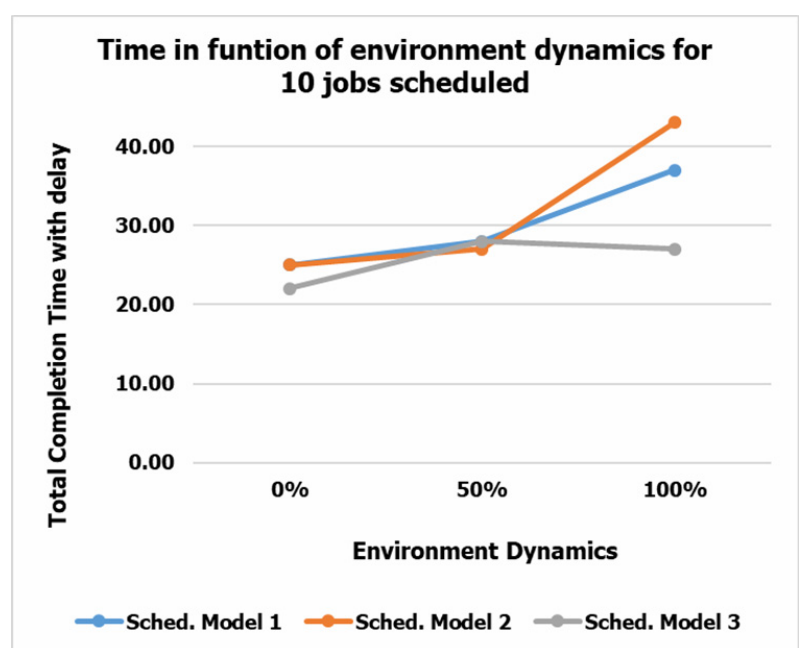

Figure 7. Effect of environment dynamics in total completion time over the 3 scheduling models for 10 jobs scheduled

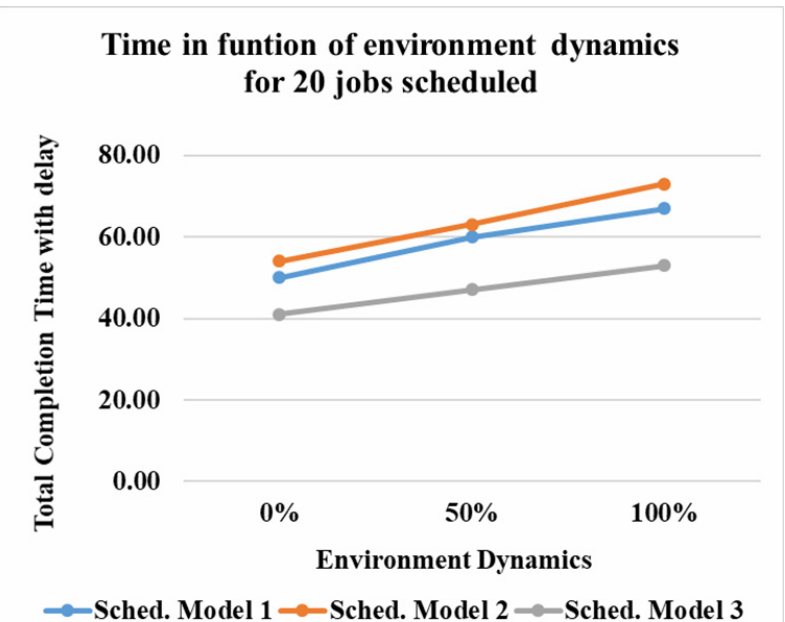

Figure 8. Effect of environment dynamics in total completion time over the 3 scheduling models for 20 jobs scheduled

Results show that the environment dynamics, i.e. different environment scenarios, affect the production schedules, especially when additional jobs are introduced in the scheduling plan.

The results for the scheduling model 1 (fixed horizon with reconfiguration scheduling paradigm) demonstrate that when it is considered the scheduling of 100 jobs, the total completion time with delay increases approximately $75.16 \%$ when compared with the environment scenario equal to $0 \%$ (i.e. a stable scenario 
with no changes in the nominal process plan) and compared with the environment scenario equal to $100 \%$ (i.e. a higher level of variation of the amplitude on the nominal process plan). Similarly to scheduling model 1 , in scheduling model 2 (rolling horizon scheduling paradigm), the total completion time with delay increases approximately $64.90 \%$.

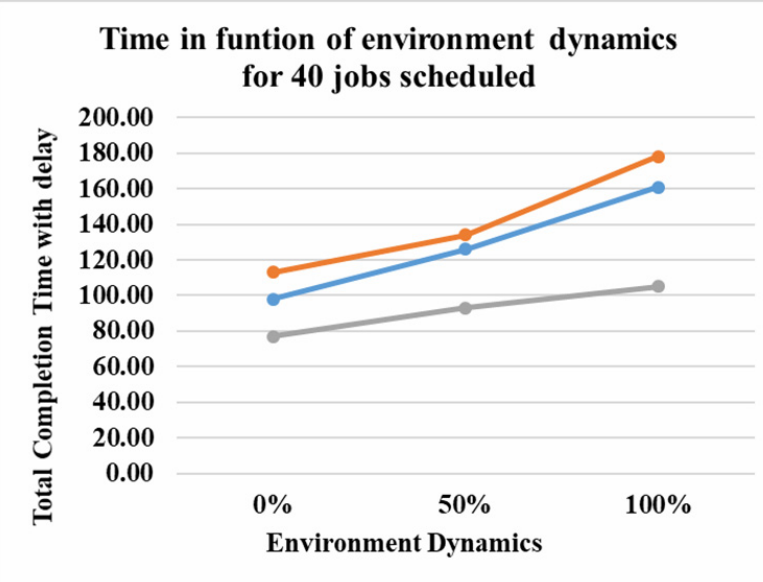

$\multimap$ Sched. Model $1 \multimap$ Sched. Model $2 \multimap$ Sched. Model 3

Figure 9. Effect of environment dynamics in total completion time over the 3 scheduling models for $\mathbf{4 0}$ jobs scheduled

Time in funtion of environment dynamics for 100 jobs scheduled

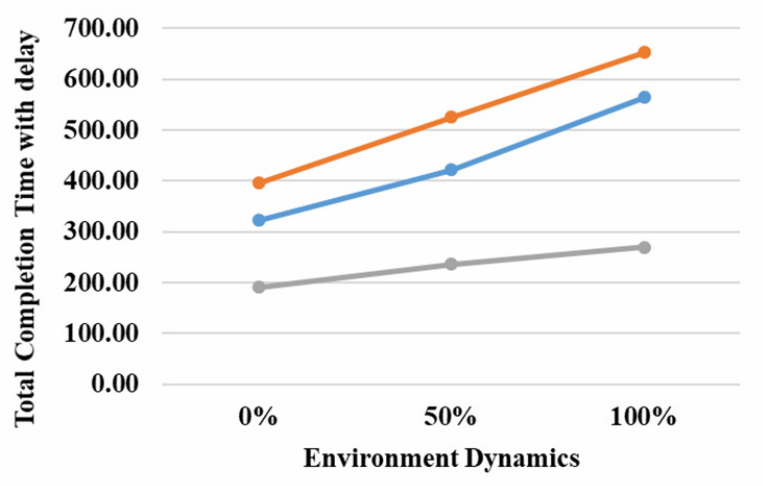

$\multimap$ Sched. Model $1 \multimap$ Sched. Model $2 \multimap$ Sched. Model 3

Figure 10. Effect of environment dynamics in total completion time over the 3 scheduling models for 100 jobs scheduled

The scheduling model 3 (real time management scheduling paradigm) simulation results, considering the 3 environment scenarios, shows less effect on production schedules, when compared with the other two scheduling models.

\subsection{Correlations between environment dynamics and total completion time with delay}

The results of the correlation analysis between environment dynamics scenarios and total completion time with delay, for scheduling of different number of jobs over different scheduling models are presented on Table 2.

Analysing correlation between environment dynamics and the total completion time with delay, the results of the effect of different environment scenarios in production schedules, over the 3 scheduling models, for $10,20,40,100$ jobs scheduled, shows a very strong or strong (in one case) positive correlation.

Table 3. Correlation table

\begin{tabular}{|c|c|c|c|c|}
\hline & \multicolumn{3}{|c|}{$\begin{array}{c}\text { Total Completion Time with } \\
\text { Delay }\end{array}$} \\
\hline & & $\begin{array}{l}\text { Sched. } \\
\text { Model } 1\end{array}$ & $\begin{array}{l}\text { Sched. } \\
\text { Model } 2\end{array}$ & $\begin{array}{l}\text { Sched. } \\
\text { Model } 3\end{array}$ \\
\hline$ㅇ ㅡ ㅇ$ & $\begin{array}{c}\text { Environment } \\
\text { scenarios } 1 \text { to } 3 \\
\end{array}$ & 0.9608 & 0.9122 & 0.7777 \\
\hline 으요 & $\begin{array}{c}\text { Environment } \\
\text { scenarios } 1 \text { to } 3\end{array}$ & 0.9948 & 0.9995 & 1.0000 \\
\hline 웡응 & $\begin{array}{c}\text { Environment } \\
\text { scenarios } 1 \text { to } 3 \\
\end{array}$ & 0.9979 & 0.9798 & 0.9966 \\
\hline 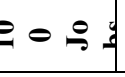 & $\begin{array}{c}\text { Environment } \\
\text { scenarios } 1 \text { to } 3 \\
\end{array}$ & 0.9950 & 0.9999 & 0.9968 \\
\hline
\end{tabular}

A strong positive correlation is obtained when the number of jobs scheduled is small (10 jobs), maybe due to the number of machines considered, were the second operation of each job can be processed, virtually, in parallel, i.e. creating a non-wait time between the operation 2 of the jobs.

\section{REQUIREMENTS FOR DEVELOPMENT OF CPPS MODELS}

CPPS integrates simulation and decision making to control and effectively change the performance of the manufacturing processes. Due to disturbances that can occur within the manufacturing system, such as, machine breakdowns, unplanned maintenance, the arrival of new and/or urgent jobs, new requests of the market, among others, the control should be more flexible to respond effectively to the environment dynamics.

The results obtained in this paper leads to the need of consideration the environment dynamics as a requirement in future CPPS models developments, to deal with the disturbances by consideration of different scenarios. Some requirements for CPPS developments are presented in literature. Galaske and Anderl [26] established some requirements for design a resilient CPPS: robustness and adaptability, self-regulation and self-recovery, short response time, intelligent component, autonomous decision, redundancy, dynamic disruption database, and escalation scenario. Other requirements has been stated by Ribeiro [27], such as (1) the nature of the control path between system components, (2) granularity of CPPS (a kind of meta-CPPS by our mean), (3) modularity, (4) functional or structural decomposition, and (4) Coupled or embedded design for management of CPPS. Monostori et al [28] presented also some requirements (expectations) for development of CPPS models, such as "robustness at every level, self-organization, self-maintenance, selfrepair, self-X, safety, remote diagnosis, real-time control, autonomous navigation, transparency, predictability, efficiency, model correctness". Antao et al [29] identified CPPS requirements: scalability, reliability, security \& privacy, timing \& determinism, safety, recovery, interoperability, reconfigurability.

In literature, presented in this paper, the environment dynamics scenarios is not considered. Thus, this paper 
contributes to the literature with the requirements for development of CPPS models: environment dynamics.

Adding the environment dynamics, i.e. considering different "future" scenarios for simulation and further decision making, the "classical" CPPS $\left(\mathrm{CPPS}^{0}\right)$, can implement full real time management to deal with the dynamic requirements over unexpected events.

The implementation of continuous real time sensors data collection, and assurance of the Big Data collection and processing (as a result of the environment model) should be also considered.

The above considerations justify the requirement that the DEMGM should be a mandatory module of a CPPS architecture.

Other requirements for development of CPPS models could be: (1) implementation of analytical models of forecasted data based on historical data, (2) consideration of different scenarios in simulation, including different organisational forms of the manufacturing systems (e.g. large and complex networks), (3) embed machine learning for analysing and generating the environment model, especially for the CPPS ${ }^{1}$ and $\mathrm{CPPS}^{2}$, and (4) implementation of different management models, according to the organisational form of the enterprises.

\section{CONCLUSIONS}

Historical data are usually used to predict the manufacturing system's behaviour. However, some unexpected disturbances can occur, forcing the reconfiguration of the manufacturing system. In production scheduling, this change implies the generation of new feasible schedules, usually different from the forecasted schedule.

An evaluation of how the environment dynamics affect the production schedules is presented, over three different scheduling paradigms: fixed horizon with reconfigurations, rolling horizon, and real time management, for different environment scenarios.

Results show the need to include the environment dynamics as a requirement for the development of CPPS models, i.e. the inclusion of the DEMGM module. In other words, it is necessary to have the capability to evaluate different scenarios, to quickly respond to disturbances and changes.

Future work should focus on the development of CPPS models with consideration of environment dynamics, considering different parameters (machine breakdowns, new products arrival, ...). Also, future work should include large and complex production networks dynamics modelling, as an environment for production scheduling in CPPS.

\section{ACKNOWLEDGMENT}

This work has been supported by FCT - Fundação para a Ciência e Tecnologia within the R\&D Units Project Scope: UIDB/00319/2020.

\section{REFERENCES}

[1] "Scenario." Merriam-Webster.com Dictionary, Merriam-Webster, https:/www.merriam-webster .com/dictionary/scenario. 2021.
[2] “Scenario." WordWeb. 2021.

[3] Wiendahl, H.-P., ElMaraghy, H.A., Nyhuis, P., Zäh, M.F., Wiendahl, H.-H., Duffie, N., Brieke, M. Changeable manufacturing-classification, design and operation. CIRP Annals-Manufacturing Technology, Vol. 56, No. 2, pp. 783-809, 2007.

[4] Vieira, G.E., Herrmann, J.W., and Lin, E. Rescheduling manufacturing systems: a framework of strategies, policies, and methods. Journal of scheduling, Vol. 6, No. 1, pp. 39-62, 2003.

[5] Ouelhadj, D., and Petrovic, S. A survey of dynamic scheduling in manufacturing systems. Journal of Scheduling, Vol. 12, No. 4, pp. 417-431, 2009.

[6] Stecca G. Scheduling. In: Chatti S., Laperrière L., Reinhart G., Tolio T. (Eds) CIRP Encyclopedia of Production Engineering. Springer, Berlin, Heidelberg, 2019.

[7] Antonelli, D., and Bruno, G. Dynamic distribution of assembly tasks in a collaborative workcell of humans and robots. FME Transactions, Vol. 47, No. 4, pp. 723-730, 2019.

[8] Rossit, D. A., Tohme, F., and Frutos, M. Production planning and scheduling in Cyber-Physical Production Systems: a review. International journal of computer integrated manufacturing, Vol. 32, No. 4-5, pp. 385-395, 2019.

[9] Lopes, N., Putnik, G., Ferreira, L., and Costa, B. Towards a high performance computing scalable implementation of Cyber Physical Systems. FME Transactions, Vol. 47, No. 4, pp. 749-756, 2019.

[10] Nikolakis, N., Senington, R., Sipsas, K., Syberfeldt, A., and Makris, S. On a containerized approach for the dynamic planning and control of a cyberphysical production system. Robotics and computer-integrated manufacturing, Vol. 64, 101919, 2020.

[11] Ghaleb, M., Zolfagharinia, H., and Taghipour, S.. Real-time production scheduling in the Industry-4.0 context: Addressing uncertainties in job arrivals and machine breakdowns. Computers \& Operations Research, Vol. 123, 105031, 2020.

[12]Zhu, K., and Zhang, Y. A cyber-physical production system framework of smart CNC machining monitoring system. IEEE/ASME Transactions on Mechatronics, Vol. 23, No. 6, pp. 2579-2586, 2018.

[13] Meissner, H., and Aurich, J.C. Implications of cyber-physical production systems on integrated process planning and scheduling. Procedia manufacturing, Vol. 28, pp. 167-173, 2019.

[14] Jiang, Z., Jin, Y., Mingcheng, E., and Li, Q. Distributed dynamic scheduling for cyber-physical production systems based on a multi-agent system. IEEE Access, Vol. 6, pp. 1855-1869, 2017.

[15] Morariu, C., Morariu, O., Răileanu, S., and Borangiu, T. Machine learning for predictive scheduling and resource allocation in large scale manufacturing systems. Computers in Industry, Vol. 120, 103244, 2020. 
[16] Shah, V., and Putnik, G.D. Machine learning based manufacturing control system for intelligent cyberphysical systems. FME Transactions, Vol. 47, No. 4, pp. 802-809, 2019.

[17] Morariu, C., and Borangiu, T. Time series forecasting for dynamic scheduling of manufacturing processes. In IEEE International Conference on Automation, Quality and Testing, Robotics (AQTR), 2018, pp. 1-6. IEEE.

[18] Gupta, D., Kumar, V., Ayus, I., Vasudevan, M., and Natarajan, N. Short-term prediction of wind power density using convolutional LSTM network. FME Transactions, Vol. 49, No. 3, pp. 653-663, 2021.

[19] Prabhu, V.V., and Duffie, N.A. Modelling and analysis of nonlinear dynamics in autonomous heterarchical manufacturing systems control. CIRP Annals-Manufacturing Technology, Vol. 44, No. 1, pp. 425-428, 1995.

[20] Scholz-Reiter, B., Freitag, M., and Schmieder, A. Modelling and control of production systems based on nonlinear dynamics theory. CIRP AnnalsManufacturing Technology, Vol. 51, No. 1, pp. 375-378, 2002.

[21] Papakostas, N., Efthymiou, K., Mourtzis, D., and Chryssolouris, G. Modelling the complexity of manufacturing systems using nonlinear dynamics approaches. CIRP Annals-Manufacturing Technology, Vol. 58, No. 1, pp. 437-440, 2009.

[22] Kozjek, D., Malus, A., Zaletelj, V., and Butala, P. Distributed control with rationally bounded agents in cyber-physical production systems. CIRP Annals-Manufacturing Technology. Vol. 67, No. 1, pp. 507-510, 2018.

[23] Abowd G.D., Dey A.K. Towards a Better Understanding of Context and Context-Awareness. In: Gellersen HW. (eds) Handheld and Ubiquitous Computing. HUC 1999. Lecture Notes in Computer Science, vol 1707. Springer, Berlin, Heidelberg. 1999.

[24] Putnik, G.D., Ferreira, L., Lopes, N., and Putnik, Z.: What is a Cyber-Physical System: Definitions and models spectrum. FME Transactions, Vol. 47, No. 4, pp. 663-674, 2019.

[25] Alves, C., and Putnik, G.D. Cyber-Physical Production System (CPPS) decision making duration time impact on manufacturing system performance. FME Transactions, Vol. 47, No. 4, pp. 675-682, 2019.

[26] Galaske, N., Anderl, R. Disruption management for resilient processes in cyber-physical production systems. Procedia CIRP, Vol. 50, pp. 442-447, 2016

[27] Ribeiro, L. Cyber-physical production systems' design challenges. In IEEE 26th international symposium on industrial electronics (ISIE), 2017, pp. 1189-1194. IEEE.

[28] Monostori, L., Kádár, B., Bauernhansl, T., Kondoh, S., Kumara, S., Reinhart, G., ... and Ueda, K. Cyber-physical systems in manufacturing. Cirp Annals, Vol. 65, No. 2, pp. 621-641, 2016.

[29] Antao, L., Pinto, R., Reis, J., and Gonçalves, G. Requirements for testing and validating the industrial internet of things. In 2018 IEEE International Conference on Software Testing, Verification and Validation Workshops (ICSTW), 2018, April, pp. 110-115. IEEE.

\section{КАКО ДИНАМИКА ПРОИЗВОДНОГ \\ ОКРУЖЕЊА УТИЧЕ НА ПРОГРАМИРАҢА ПРОИЗВОДЫЕ: ЗАХТЕВИ ЗА РАЗВОЈ МОДЕЛА САЈБЕР-ФИЗИЧКИХ ПРОИЗВОДНИХ СИСТЕМА (СФПС)}

\section{К. Алвеш, Г. Д. Путник, Л. Варела}

На програмиранје производње могу утицати многи поремећаји у производном систему, па су, последично, претходно дефинисани производни програми застарели. Појава нових технологија повезаних са Индустријом 4.0, као што су Сајбер-Физички Производни Системи (СФПС), као парадигма имплементације контроле и подршке у доношењу одлука, требало би да имају уграђене капацитете за симулацију различитих сценарија окружења на основу података које прикупљених од стране самих производних система. Овај рад представља оцену утицаја динамике производног окружења на програмирање производње, узимајући у обзир три модела програмирања и три сценарија производног окружења, кроз студију случаја. Резултати показују да динамика производног окружења утиче на програмирање производње, и да постоји врло јака или јака позитивна корелација између сценарија динамике производног окружења и укупног завршног времена са кашњењем, преко три парадигме програмирања проиводње. На основу ових резултата потврђен је захтев за обавезним уграђивањем модула за генерисање различитих сценарија динамике производног окружења и одговарајуће симулације у архитектуре Сајбер-Физичких Производних Система. 